\title{
Gallon British
}

National Cancer Institute

\section{Source}

National Cancer Institute. Gallon British. NCI Thesaurus. Code C48582.

A traditional unit of volume designed to contain 10 pounds of distilled water under precisely defined conditions and equal to 4.546091 liters, 277.4194 cubic inches, or 1.20095 US liquid gallons, or 1.03206 US dry gallons. 